\title{
Oil Quality Characteristics and Effects of TemperatureVariations on Some Functional Properties of Horse Eye (Dioclea reflexa) Seed Flour.
}

\author{
G.O. Oyeleke ${ }^{1}$, O. Afolabi ${ }^{1,}$ O.A. Olayiwola ${ }^{2}$, R.O Adetoro ${ }^{3}$. \\ ${ }^{1}$ Science Laboratory Technology Department, Osun State Polytechnic, Iree, Nigeria. \\ ${ }^{2}$ Applied Sciences Department, Osun State Polytechnic, Iree, Nigeria. \\ ${ }^{3}$ Chemistry Department, Osun State College of Education, Ila-Orangun, Nigeria.
}

\begin{abstract}
This study is the second of two publications that investigates the nutritional composition of horse eye (Dioclea reflexa) seed in terms of some functional and physicochemical properties of the seed and the seed-oil. The functional properties of the seed flour revealed that the water absorption capacity (WAC) was 94.67 $\pm 0.05 \%$, conductivity $1856 \mathrm{us} / \mathrm{cm}$. The effects of temperature variations on swelling and solubility powers in \% were (159.12 \pm 0.02 and $8.00 \pm 0.10)$, (157.48 \pm 0.10 and $7.92 \pm 0.50)$, (153.88 \pm 0.20 and $5.36 \pm 0.06)$ and $(129.96$ \pm 0.40 and $2.12 \pm 0.02)$ at $65^{\circ} \mathrm{C}, 75^{\circ} \mathrm{C}, 85^{\circ} \mathrm{C}$ and $95^{\circ} \mathrm{C}$ respectively. The physicochemical properties showed specific gravity to be $0.9456 \mathrm{~g} / \mathrm{cm}$, saponification value $(197.88 \pm 0.20 \mathrm{mgKOH} / \mathrm{g})$, iodine value $(152.44$ $\pm 0.10 \mathrm{gI} / \mathrm{l} / \mathrm{gg})$, peroxide value $(9.97 \pm 0.05 \mathrm{meq} / \mathrm{kg})$ and acid value $(6.934 \pm 0.10 \mathrm{mgKOH} / \mathrm{g})$. The vitamin $\mathrm{C}$ content of the seed-oil was found to be $4.98 \pm 0.50 \%$. The results of this research work revealed that Dioclea reflexa seed and seed-oil could be a good replacement to the ever increasing demand for conventional oils and flours after proper refining.
\end{abstract}

Keywords: Dioclea reflexa, seed, seed-oil, flour, physicochemical, functional, replacement, refining.

\section{Introduction}

Dietary habits rich in plant food products have been related to a decrease in mortality by cardiovascular diseases and cancer [1]. Plants are essential in our everyday existence because they provide foods and also serve as raw materials for many industrial products such as clothes, foot wears and so many others. The use of plants in traditional medical practice has a long drawn history and remains the mainstay of primary health care in most of the third world [2]. Malnutrition is a major health problem in Africa, despite government efforts to promote food production. Human beings required food to grow, reproduce and maintain good health. Without food, our bodies could not stay warm, build or repair tissues or maintain heartbeat [3].

Oil can be said to be greasy substance that is liquid at room temperature and insoluble in water. They are heterogeneous collection of biochemical substances which have in common, the property of being soluble in most organic solvents. Vegetable oils and fats have wide application in foods where they are used in frying, salad dressing, shortening of pastry, margarine, cooking and ice cream manufacture [4]. Essential oils are also valuable natural products used as raw materials in many fields including perfumes, cosmetics, aromatherapy, phytotherapy, spices and nutrition. Essential oils are complex mixtures comprising many single compounds and each of these constituents contributes to the beneficial or adverse effects of these oils [5]. Edible wild plants have been reported to provide alpha-linolenic acid and several polyunsaturated fatty acids in addition to their major natural sources of fat tissues of ruminant's meat and dairy products [6]. Processing methods such boiling, drying, fermentation, autoclaving, dehulling, milling etc at various conditions and temperatures has been some of the major ways of improving the quality of food materials.

Several seeds abounds in Africa especially Nigeria that could be utilized to meet up with the ever increasing population in terms of oil, protein and other nutrients. Among those seeds is horse eye (Dioclea reflexa) which is a leguminous plant of fabaceae family. It is a woody vine widely distributed within the tropical Africa and South America. It is also a very common seed in South- western part of Nigeria. There are many studies on the nutrient composition of the seeds $[7,8]$ but scanty information is available on the physicochemical properties of the seed-oil as well as the effects of temperature variations on selected functional properties of the seed because most of the food materials consumed in this part of the world needs to be processed very well before consumption.

This study therefore aimed at determining selected physicochemical and functional properties of the seed and seed-oil of Dioclea reflexa with a view to contribute to the existing knowledge of the potential of this seed. 


\subsection{Materials}

\section{Materials And Methods}

\subsection{Sampling and Sample Preparation}

The dried seeds of Dioclea reflexa used for this research work were collected from a farm at Iree, Boripe Local Government area of Osun State, Nigeria. The outer thick coats were removed manually while the hard, inner parts were grinded using a giant laboratory blender (Phillip's Harris model). The ground seeds were passed through a $2 \mathrm{~mm}$ sieve, oven dried at $70^{\circ} \mathrm{C}$ to a constant weight and kept inside a tight polythene bag ready for further analysis.

\subsection{Methodology}

Functional properties for water absorption capacity and swelling properties of the seed flour were determined using the methods of Appiah et al., [9]. The solubility power for the flour was done by the method described by Akin-Osanaiye et al., [10], the temperature for swelling and solubility tests were however varied from $65^{\circ} \mathrm{C}-95^{\circ} \mathrm{C}$ at $10^{\circ} \mathrm{C}$ interval. The extraction of the oil from the seed was done using solvent extraction (Soxhlet) method as described by Rashid et al., [11]. The physicochemical properties of the extracted oil were carried out for saponification and iodine values using the methods of Mansor et al., [12] while the specific gravity, vitamin C, peroxide and acid values were done using the AOAC [13] methods.

\subsection{Results}

\section{Results and Discussion}

Table 1: Selected Functional Properties of the Seed Flour.

\begin{tabular}{lc}
\hline Parameter & Value \pm S.D \\
\hline Water absorption capacity $(\%)$ & $94.67 \pm 0.05$ \\
Conductivity $($ us $/ \mathrm{cm})$ & $1856 \pm 5$ \\
Swelling power $(\%)$ & \\
$65^{\circ} \mathrm{C}$ & $159.12 \pm 0.02$ \\
$75^{\circ} \mathrm{C}$ & $157.48 \pm 0.10$ \\
$85^{\circ} \mathrm{C}$ & $153.88 \pm 0.20$ \\
$95^{\circ} \mathrm{C}$ & $129.96 \pm 0.40$ \\
Solubility power $(\%)$ & \\
$65^{\circ} \mathrm{C}$ & $8.00 \pm 0.10$ \\
$75^{\circ} \mathrm{C}$ & $7.92 \pm 0.50$ \\
$85^{\circ} \mathrm{C}$ & $5.36 \pm 0.06$ \\
$95^{\circ} \mathrm{C}$ & $2.12 \pm 0.02$ \\
\hline $\mathrm{n}=2$ &
\end{tabular}

Table 2: Physicochemical Properties of the Oil.

\begin{tabular}{lc}
\hline Parameter & Value $=\mathrm{S} . \mathrm{D}$. \\
Specific gravity $\left(\mathrm{g} / \mathrm{cm}^{3}\right)$ & 0.9456 \\
Saronification value $(\mathrm{mgKOH} / \mathrm{g})$ & $197.88 \pm 0.20$ \\
Iodine value $(\mathrm{gI} / 100 \mathrm{~g})$ & $152.44 \pm 0.10$ \\
Peroxide value $(\mathrm{meg} / \mathrm{Kg})$ & $9.97 \pm 0.05$ \\
Acid value $(\mathrm{mg} / \mathrm{KOH} / \mathrm{g})$ & $6.93 \pm 0.10$ \\
Vitamin C $(\%)$ & $4.98 \pm 0.05$ \\
\hline
\end{tabular}
$\mathrm{n}=2$

Table 3: Decrease in Solubility and Swelling Properties (\%).

\begin{tabular}{lcc}
\hline Temperature & Solubility & Swelling Power \\
\hline $65^{\circ} \mathrm{C}$ & - & \\
$75^{\circ} \mathrm{C}$ & 1 & 1 \\
$85^{\circ} \mathrm{C}$ & 33 & 3 \\
$95^{\circ} \mathrm{C}$ & 74 & 18 \\
\hline
\end{tabular}

\subsection{Discussion}

The result for functional properties of the seed flour is presented in table 1. The water absorption capacity (WAC) was found to be $94.67 \pm 0.05 \%$. This value was lower than those reported for some cowpea varieties in Ghana and Nigeria respectively $[9,14]$. The value obtained here for WAC suggests less availability of polar amino acids in the flour. WAC as a functional property is a useful parameter for several bakery products. The conductivity for the seed flour revealed a value of $1856+5 \mathrm{us} / \mathrm{cm}$, this value is important in determining the characteristic behaviour of the seed flour for industrial usage.

Swelling power (\%) of the seed flour was found to decrease as the temperature increases; $65^{\circ} \mathrm{C}(159.12 \pm 0.02)$, $75^{\circ} \mathrm{C}(157.48 \pm 0.10), 85^{\circ} \mathrm{C}(153.88 \pm 0.20)$ and $95^{\circ} \mathrm{C}(129.96 \pm 0.04)$ showing a decrease of $1 \%, 3 \%$ and $18 \%$ 
from $65^{\circ} \mathrm{C}$ to $95^{\circ} \mathrm{C}$ respectively. The major factor that affects the swelling behaviour is the strength and character of the micelle network within the granule. Presence of substances such as lipids or phosphate groups also affects swelling [15] and since the seed flour is a legume, it will contain high level of lipids; the influence on swelling power would therefore be substantial. This definitely accounted for the low swelling values.

The solubility power (\%) followed the same trend as for the swelling power from $65^{\circ} \mathrm{C}(8.00 \pm 0.10)$, $75^{\circ} \mathrm{C}(7.92 \pm 0.50), 85^{\circ} \mathrm{C}(5.36 \pm 0.06)$ and $95^{\circ} \mathrm{C}(2.12 \pm 0.02)$. These values showed a decrease of $1 \%, 33 \%$ and $74 \%$ from values reported at $65^{\circ} \mathrm{C}$ to $95^{\circ} \mathrm{C}$ respectively which shows that the (\%) decrease in solubility power is far more than the swelling power of the seed. The reduction in the swelling and solubility powers of the seed flour with increase in temperature could be attributed to the alteration in the internal granule structure that could results in reduction of the cohesiveness and other textural components of the flour. [15].

Table 2 showed some physicochemical properties of Dioclea reflexa seed oil. The specific gravity for the seed oil was 0.9456. The value is similar to 0.945 reported for Pumpkin seed oil [16]. The value showed that the oil is less dense than water.

The saponification value of the Dioclea reflexa seed oil was $197.88 \pm 0.20 \mathrm{mgKOH} / \mathrm{g}$. This high value shows that more alkali would be needed to enable it neutralize the available free fatty acid liberated by the oil [16]. The result is similar to that of typical seed oils such as Sunflower, corn and safflower oils [17] whose average saponification value range from $175-250 \mathrm{mgKOH} / \mathrm{g}$ which suggests that the seed oil under examination has high potential for use in the production of liquid soap and shampoos [18].

The iodine value (I.V) of $152.44 \pm 0.10 \mathrm{gI}_{2} / 100 \mathrm{~g}$ was obtained for the seed oil. Oils are classified into drying, semi-drying and non-drying according to their iodine values. A good drying oil should have I.V of 180 [19], since the iodine value obtained is higher than 100, it is classified as semi-drying oil and would not attract high interest in the paint and coating industries. This problem could be solved by allowing the oil to undergo dehydration before use [20]. The relative high I.V is a pointer to the presence of high percentage of unsaturated fatty acids in the seed oil; as such the amount of iodine that will be absorbed by the unsaturated acids would be higher [16] and oils with such characteristic may therefore be find useful as raw materials in the manufacture of vegetable oil-based ice cream [21].

Peroxide value of $9.97 \pm 0.05 \mathrm{meqKOH} / \mathrm{g}$ obtained for the oil was high compared to $2.26 \mathrm{meqKOH} / \mathrm{g}$ reported for Telfairia occidentalis [22]. The $9.97 \pm 0.05 \mathrm{meqKOH} / \mathrm{g}$ obtained was nearly equal to $0-10 \mathrm{meqKOH} / \mathrm{g}$ set by Codex Alimentarius commission for groundnut seed oil [23], thus the oil may not be completely stable towards oxidation and storage for a long time may lead to rancidity of the oil. Certain antioxidants such as propyl gallate may however be used to reduce rancidity of oil [16]. The acid value of $6.93 \pm 0.10 \mathrm{mgKOH} / \mathrm{g}$ reported for this oil is outside the range of 0 to $3 \mathrm{mgKOH} / \mathrm{g}$ recommended for any oil to find application in cooking [21]. This value is very much higher than $0.953 \mathrm{mgKOH} / \mathrm{g}$ and $3.48 \pm 1.60 \mathrm{mgKOH} / \mathrm{g}$ for sunflower and Telfairia occidentalis $[4,22]$ but lower than $19.035 \mathrm{mgNaOH} / \mathrm{g}$ and $12.903 \mathrm{mgNaOH} / \mathrm{g}$ reported for palm kernel oil and Breadfruit oil [16]. The high acid value suggests that the oil will be more susceptible to lipase action. These parameters can be made fit by subjecting the oil to refining which may also improve the oil quality for industrial purposes [21].

The vitamin C content of the oil was found to be $4.98 \pm 0.50 \%$. This value is a little bit low but could still be utilized as a cheap source of vitamin $\mathrm{C}$ supplement to the body.

\section{Conclusion}

The findings of this study showed that Dioclea reflexa seed oil could be exploited for domestic and industrial purposes after proper refining. The seed flour could also play some functional roles in food industries. The research work also revealed the effects of temperature variations on solubility and swelling properties of the seed flour which will be of great assistance in food industries in determining the stability of the flour during and after processing.

\section{Acknowledgement}

One of the authors (G.O.O.) acknowledged the contributions of his 2011/2012 National Diploma (SLT) research students (DPT) for their contributions in collecting of samples and data.

\section{References}

[1] B. Cerda, P. Periago, J.C. Espin, and F.A., Tomas-Barberan, Identification of Urolithin A as a Metabolite produced by Human Colon Microflora from Ellagic acid and Related Compounds, J. Agric. \& Food Chem., 53, 2005, 5571-5576.

[2] A.O.Adesuyi, I.K. Elumm, F.B. Adaramola, and A.G.M. Nwokocha, Nutritional and Phytochemical Screening of Garcinia kola, Advan. Jour. Food Sci. and Technol. 4(1), 2012, 9-14.

[3] S.M. Dangoggo, M.I. Bunu, A. Uba and Y. Saidu, Study of Proximate, Mineral and Antinutrient Composition of Punica granatum Seeds from North-Western Nigeria and Saudi Arabia. Research 4 (4), 2012, 4-9.

[4] M.A. Aboki, M. Mohammed, S.H. Musa, B.S. Zuru, H.M. Aliyu, M. Gero, I.M. Alibe and B. Inuwa, Physicochemical and Antimicrobial Properties of Sunflower (Helianthus annuus L.) seed oil, Int. Jour. of Sci. \& Techn., Vol. 2 No 4, $2012,151-154$.

[5] M. Lahlou, Methods to study the Phytochemical and Bioactivity of Essential oils, Phytotheraphy Research, 18, 2004, 435-448. 
[6] N.L. Flintofff-Dye and S.T. Omaye, Antioxidant Effect of Conjugated Iinoleic acid Isomers in human Low-Density Lipoproteins, Nutr. Res. 25, 2005, 1-12.

[7] A.A. Akinyede, I.A. Amoo and A.F. Eleyinmi, Chemical and Functional Properties of Full fat and Defatted Dioclea reflexa seed flour, Journal of Food Agric. \& Environ. Vol. 3 Issue 2, 2005, 112-115.

[8] A.A. Yusuf and A.A. Lasisi, Compositional Analysis of Horse eye (Dioclea reflexa) Seed Flour and its Cake, Agric. Journal, Issue 1, Vol. 1 2006, 28-31.

[9] F. Appiah, J.Y. Asibuo and P. Kumah, Physicochemical and Functional Properties of Bean Flours of three Cowpea (Vigna unguiculata L. Walp) Varieties in Ghana, Afr. Jour. Food Sci., Vol. 5(2), 2011, 100-104.

[10] B.C. Akin-Osanaiye, A.S. Agbaji, E.B. Agbaji and O.M. Abdulkadir, Proximate Composition and the Functional Properties of Defatted Seed and Protein Isolates of Kargo seed (Piliostigma reticulatum), AJFAND, Vol. 9 No 6, 2009, $1366-1377$.

[11] U. Rashid, F. Anwar, B.K. Moses and S. Ashraf, Production of Sunflower oil Methyl esters by Optimized Alkali-Catalyzed Methanolysis, Biomass Bioenergy, 32, 2008, 1202-1205.

[12] T.S.T. Mansor, Y.B. Cheman, M. Shuhaimi, M.J. Abdul Afig and F.K.M. Ku Nurul, Physicochemical Properties of Virgin Coconut oil Extracted from Different Processing Methods, Int. Food Res. J. 19(3), 2012, 837-845.

[13] AOAC, Official Methods of Analysis, $15^{\text {th }}$ Edition (1990), Association of Official Analytical Chemists, Washington D.C.

[14] C.E. Chinma, I.C. Alemede and I.G. Emelife, Physicochemical and Functional Properties of some Nigerian Cowpea Varieties, Pak. J. Nutr, 7(1), 2008, 186-190.

[15] F.A. Numfor, W.M. Walter Jr. and S.J. Schwartz, Physicochemical Changes in Cassava Starch and Flour Associated with Fermentation: Effect on Textural Properties, Starch/Starke, 47, 1995, Nr. 3. S. 86-91.

[16] S.O.O. Eze, Physicochemical Properties of Oil from some Selected Underutilized Oil Seeds available for Biodiesel Preparation, Afri. Jour. Biotech., Vol. 11(42), 2012, 10003-10007.

[17] R.D. O'Brien, Fats and Oils: Formulating and Processing for Applications, $2^{\text {nd }}$ Ed., CRC Pubishing, 2004, Washington DC.

[18] C.S. Ku and S.P. Mun, Characterization of Seed oils from Bokbunja (Rubus coreanus Mig.) and Wine Processing Waste, Bioresource Technology, 99, 2007, 4503-4509.

[19] O.J. Abayeh, E.A. Aina and C.O. Okuonghae, Oil content and Oil Quality Characteristics of some Nigerian Oil Seeds, J. Pure \& Appl. Sci., 1, 1998, 17-23.

[20] M.I. Mohammed and Z.U. Hamza, Physicochemical Properties of oil Extracts from Sesamum indicum L. seeds Grown in Jigawa State- Nigeria, J. Appl. Sci. Environ. Manage. Vol. 12 (2), 2008, 99-101.

[21] K.A. Oderinde, I.A. Ajayi and A. Adewuyi, Characterization of Seed and Seeds oil of Hura crepitans and the Kinetics of Degradation of the Oil during Heating, Electro. J. Environ. Agric. Food Chem. 8(3), 2009, 201-208.

[22] M.O. Bello, T.L. Akindele, D.O. Adeoye and A.O. Oladimeji, Physicochemical Properties and Fatty Acids profile of Seed oil of Telfairia occidentalis Hook, F. Int. Jour. of Basic and Appli. Sci. Vol. 11 No. 6, 2011, 9-14.

[23] Codex Alimentarius Commission, Codex Standard for named Vegetable Oils, Food and Agricultural Organization of the United Nations, World Health Organization (WHO), Vol. 8, 2001, Rome.

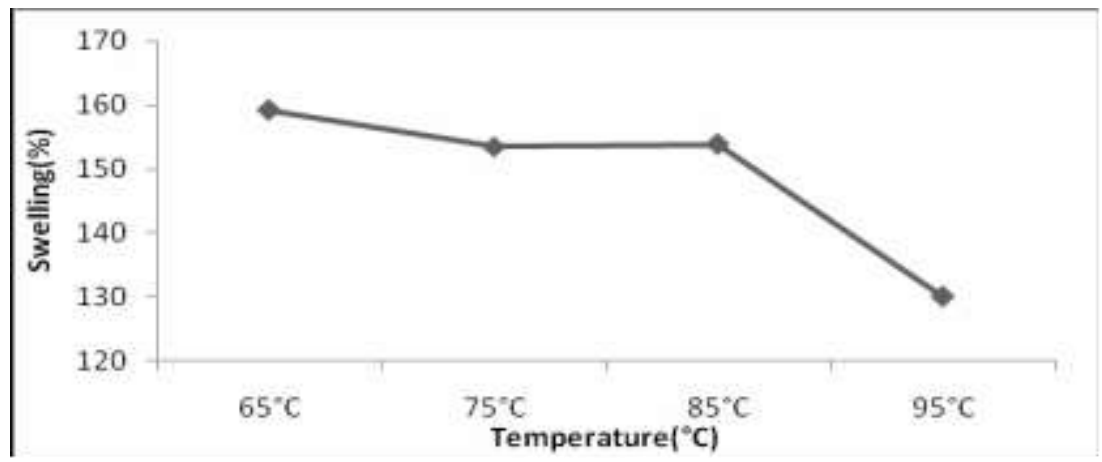

Fig. 1: Temperature and Percentage Swelling.

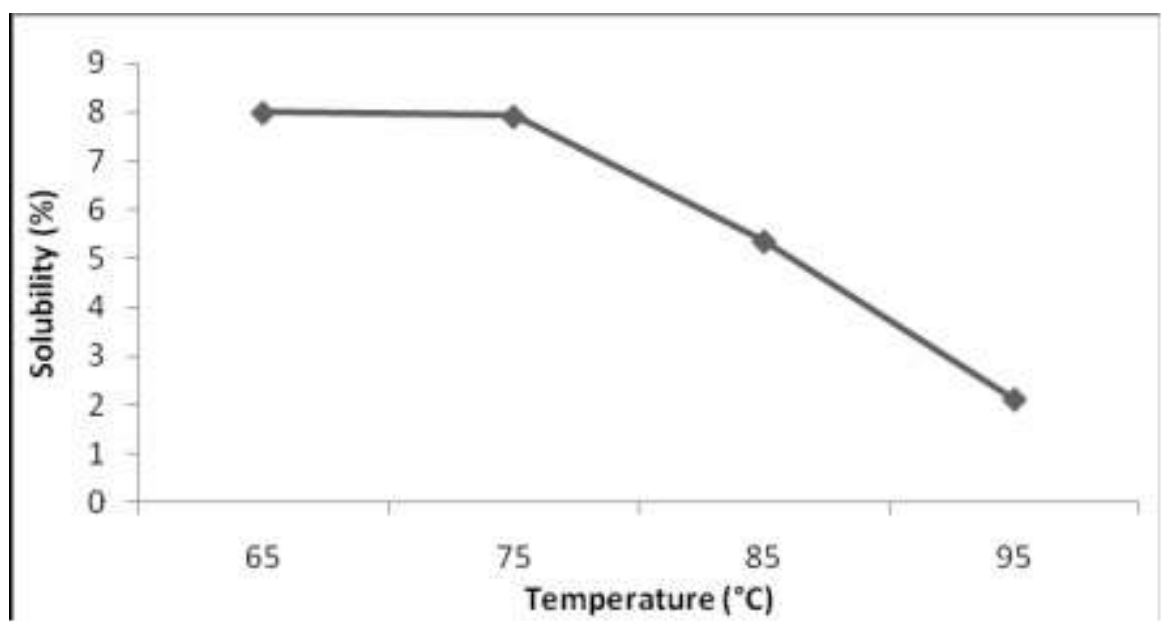

Fig. 2: Temperature and Percentage Solubility. 


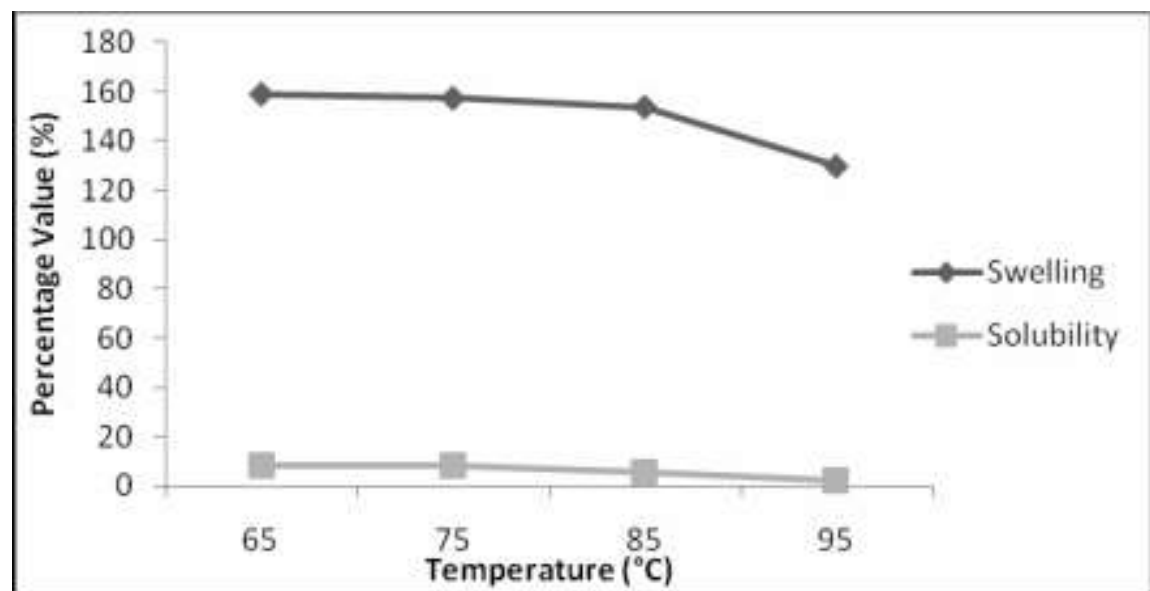

Fig. 3: Comparative (\%) Swelling and Solubility at Various Temperatures.

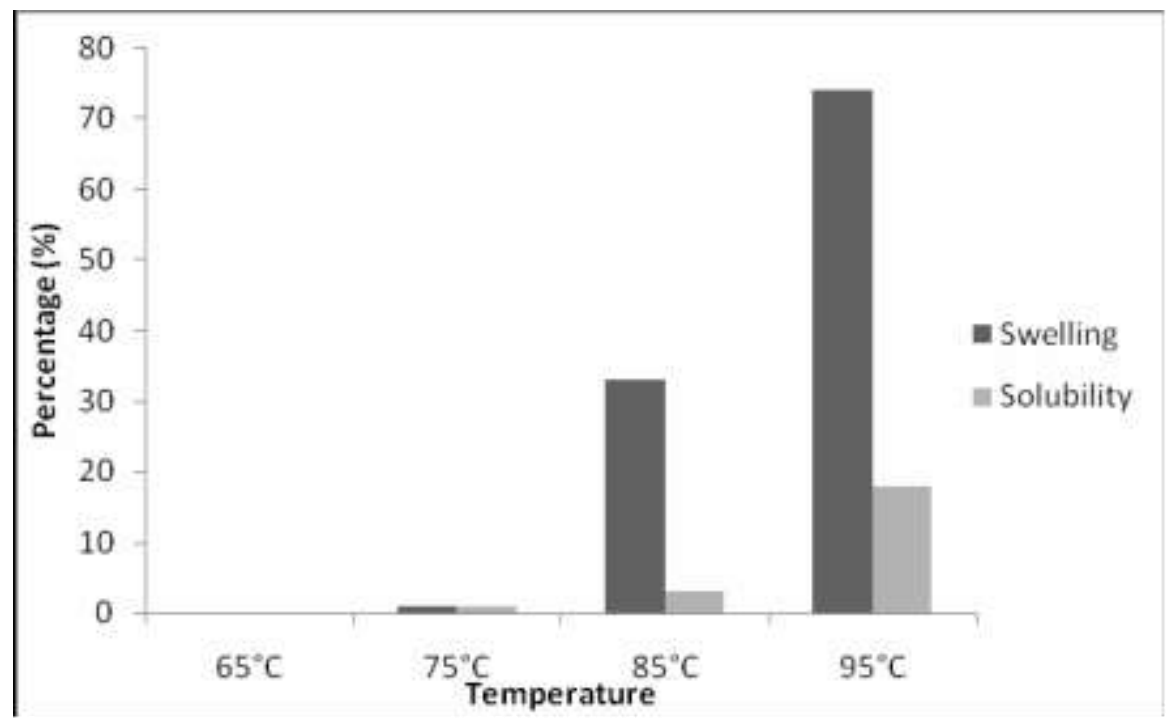

Fig. 4: Comparative (\%) Decrease in Swelling and Solubility at Various Temperatures 